\title{
Pengaruh Pemberian Cendawan Mikoriza Arbuskula (CMA) dan Dosis Pupuk Kandang Ayam terhadap Pertumbuhan Dan Produksi Jagung (Zea mays L.)
}

\author{
Effect of Vesicle Arbuscular Mycorrhiza (VAM) and Chicken Manure Dose \\ Toward Growth and Production of Maize (Zea mays L.)
}

\author{
Rani Farida dan M. A. Chozin \\ Departemen Agronomi dan Hortikultura, Fakultas Pertanian, Institut Pertanian Bogor \\ (Bogor Agricultural University), J1. Meranti, Kampus IPB Darmaga, Bogor 16680, Indonesia \\ Telp.\&Faks.62-251-8629353 e-mail agronipb@indo.net.id \\ *Penulis untuk korespondensi: ma_chozin@yahoo.com
}

Disetujui 14 November 2015 /Published online 12 Desember 2015

\begin{abstract}
The application of VAM and chicken manure dose was investigated toward growth and production of maize using splitplot design by complete randomized design methode. The first factor as the main plot is VAM (without VAM and with VAM) and the second factor as subplot is the dose of chicken manure $(0,5,10$, 15, and 20 ton $\left.\mathrm{ha}^{-1}\right)$. Doses of chiken manure 0 ton $\mathrm{ha}^{-1}$ was used to determine $100 \%$ inorganic fertilizer and the other dose of chicken manure was used to determine 50\% of inorganic fertilizer. Statistically, the application of the VAM did not provide significant effect on the growth and yield of maize. However, at 9 weeks after planting, the use of VAM provide more high-than plant height without the use of VAM. In several treatment with VAM showed growth and higher production than without VAM. Application doses of chicken manure showed a significant effect on the growth and yield of corn. Doses of chicken manure give a linear response of plant height at 9 week after planting and corn grains.
\end{abstract}

Keywords: fertilizer, plant height, treatment, yield

\begin{abstract}
ABSTRAK
Pemberian VAM dan dosis pupuk kandang ayam telah diteliti terhadap pertumbuhan dan produksi jagung menggunakan rancangan split plot dengan rancangan lingkungan rancangan kelompok lengkap teracak. Faktor pertama sebagai petak utama adalah VAM (tanpa VAM dan dengan VAM) dan faktor kedua sebagai anak petak adalah dosis pupuk kandang ayam $\left(0,5,10,15\right.$, dan 20 ton ha $\left.{ }^{-1}\right)$. Dosis pupuk kandang ayam 0 ton ha $^{-1}$ digunakan untuk menentukan $100 \%$ pupuk anorganik dan dosis lain dari pupuk kandang ayam digunakan untuk menentukan 50\% dari pupuk anorganik. Secara statistik, penerapan VAM tidak memberikan pengaruh yang nyata terhadap pertumbuhan dan produksi jagung. Penggunaan VAM memberikan tinggi tanaman lebih tinggi dari tinggi tanaman tanpa menggunakan VAM pada 9 minggu setelah tanam. Beberapa perlakuan dengan VAM menunjukkan pertumbuhan dan produksi yang lebih tinggi dibandingkan tanpa VAM. Pemberian dosis pupuk kandang ayam menunjukkan pengaruh yang nyata terhadap pertumbuhan dan produksi jagung. Dosis pupuk kandang ayam memberikan respon linear pada tinggi tanaman saat 9 minggu setelah tanam dan jagung berbiji.
\end{abstract}

Kata kunci: panenan, perlakuan, pupuk, tinggi tanaman 


\section{PENDAHULUAN}

Jagung selain digunakan sebagai bahan pangan juga digunakan sebagai bahan pakan ternak dan bahan baku industri. Sektor peternakan yang terus berkembang dengan diiringi peningkatan industri pangan dan pakan membuat kebutuhan jagung dalam negeri terus mengalami peningkatan. Hal ini membuat kebutuhan akan jagung terus meningkat. Data BPS (2011) menunjukkan produktivitas jagung di Indonesia pada tahun 2009 sebesar 4.24 ton $\mathrm{ha}^{-1}$ dan mengalami peningkatan sebesar $4.48 \%$ pada tahun 2010 menjadi 4.43 ton $\mathrm{ha}^{-1}$ namun pada tahun 2011 produktivitas diramalkan mengalami penurunan menjadi 4.41 ton $\mathrm{ha}^{-1}$.

Terjadinya ketidakseimbangan antara laju produksi dan kebutuhan akan jagung antara lain disebabkan oleh rata-rata hasil produksi jagung ditingkat petani relatif masih rendah. Hal tersebut dapat disebabkan oleh kehilangan bahan organik pada lahan pertanian yang terangkut dalam bentuk hasil panen, pembakaran sisa panen, dan erosi tanah. Pupuk memegang peran penting dalam meningkatkan produksi pertanian termasuk jagung.

Penggunan berbagai jenis pupuk telah dilakukan dalam upaya peningkatan unsur-unsur hara yang hilang. Penggunaan pupuk anorganik memberikan dampak yang nyata yaitu dapat menyediakan unsur hara yang banyak dan langsung diserap oleh tumbuhan dalam waktu yang relatif singkat. Akan tetapi, penggunaan pupuk anorganik ternyata memiliki kelemahan antara lain dapat menyebabkan kerusakan struktur tanah seperti tanah menjadi lebih keras dan $\mathrm{pH}$ tanah menjadi lebih masam.

Penambahan input pupuk berupa pupuk anorganik sebaiknya dikombinasikan dengan penggunaan pupuk organik atau pupuk hayati, dengan sistem ini kesuburan tanah dapat dikembalikan sehingga daur ekologis dapat kembali berlangsung dengan baik dengan memanfaatkan mikroorganisme tanah sebagai penyedia produk metabolit untuk nutrisi tanaman. Penggunaan pupuk anorganik dapat dikurangi melalui penggunaan pupuk organik atau pupuk hayati. Menurut Mugnisjah (2008), konsep pertanian yang mengupayakan keberkelanjutan dengan meminimalkan masukan luar serta memperhatikan dampak

negatif dari kegiatan pertanian dikenal dengan istilah LEISA (Low-External-Input and Sustainable Agriculture).
Pupuk organik yang banyak digunakan oleh petani salah satunya yaitu pupuk kandang ayam. Pupuk kotoran ayam mengandung nitrogen (N) tiga kali lebih besar daripada pupuk kandang lain serta kandungan fosfor (P) yang cukup tinggi. Berdasarkan hasil penelitian Yusnaini (2009) menyatakan bahwa penggunaan bahan organik terutama kotoran ayam dapat memperbaiki kualitas tanah sehingga produksi tanaman jagung mengalami peningkatan dan tidak berbeda dengan penggunaan pupuk anorganik $100 \%$.

Upaya lain yang dapat dilakukan untuk mengatasi kondisi tanah sebagai media tumbuh tanaman yaitu dengan penggunaan teknologi berbasis mikroba, seperti penggunaan mikoriza. Tanaman yang bersimbiosis dengan CMA pertumbuhannya relatif lebih baik bila dibandingkan dengan tanaman yang tidak bersimbiosis dengan CMA. Hasil penelitian menunjukkan bahwa terdapat interaksi yang nyata antara inokulasi mikoriza, bahan organik, dan aplikasi fosfat alam pada luas daun mentimun (Rosliani et al., 2006). Hal ini didukung oleh temuan yang menyatakan bahwa pada bibit sawit, tanaman yang diberi mikoriza mempunyai jumlah daun yang lebih banyak dibandingkan dengan tanaman yang tidak diinokulasi dengan mikoriza (Wachjar et al., 2002; Mayerni dan Hervani, 2008). Peningkatan serapan air dan hara menyebabkan produksi biomas khususnya pada bagian atas tanaman (batang dan daun) juga ikut meningkat dengan pemberian cendawan mikoriza, namun tidak berbeda nyata pada biomas akar (Mawardi dan Djazuli, 2006). Peningkatan kolonisasi CMA pada akar tanaman akibat pemberian kotoran ayam, selain disebabkan oleh peningkatan bahan organik tanah dan $\mathrm{pH}$, juga kemungkinan disebakan oleh tingginya kandungan $\mathrm{P}$ dan kalsium pada kotoran ayam (Yusnaini, 2009).

Penggunaaan pupuk organik yang berupa pupuk kotoran ayam dan pupuk hayati yang berupa CMA, diharapkan mampu meningkatkan pertumbuhan dan produksi jagung secara optimal. Penelitian ini bertujuan untuk mengetahui pengaruh pupuk kandang ayam yang dikombinasikan dengan cendawan mikoriza arbuskula terhadap pertumbuhan dan produksi jagung.

\section{BAHAN DAN METODE}

Penelitian ini dilaksanakan di Kebun Percobaan Leuwikopo IPB Darmaga Bogor pada ketinggian $240 \mathrm{~m}$ dpl dengan jenis tanah Latosol. 
Analisis derajat infeksi akar oleh CMA dilakukan di Laboratorium Pusat Penelitian Sumberdaya Hayati dan Bioteknologi LPPM IPB. Penelitian ini dilaksanakan pada bulan Januari hingga Mei 2011.

Bahan yang digunakan yaitu benih jagung varietas Bisma sebanyak $25 \mathrm{~kg} \mathrm{ha}^{-1}$, pupuk kandang ayam, pupuk anorganik berupa pupuk urea, SP-18 dan $\mathrm{KCl}$, inokulan campuran CMA dari Balai Penelitian Tanaman Obat dan Aromatik (Balittro) Bogor, karbofuran, dan kapur dolomite. Alat yang digunakan dalam penelitian ini adalah seperangkat alat budidaya pertanian, ajir, timbangan, dan karung.

Rancangan yang digunakan berupa Rancangan Split Plot dengan rancangan lingkungan berupa rancangan kelompok lengkap teracak (RKLT) dengan dua faktor perlakuan dan tiga ulangan. Faktor pertama sebagai petak utama yaitu CMA yang terdiri dari 2 perlakuan yaitu tanpa CMA (M0) dan dengan CMA sebanyak 10 g per tanaman (M1). Faktor kedua sebagai anak petak yaitu pupuk kandang ayam yang terdiri dari 5 taraf yaitu: 0 ton $\mathrm{ha}^{-1}$ (A0); 5 ton ha ${ }^{-1}$ (A1); 10 ton ha ${ }^{-1}$ (A2); 15 ton ha ${ }^{-1}$ (A3); dan 20 ton ha ${ }^{-1}$ (A4). Terdapat 10 kombinasi perlakuan dengan 3 ulangan sehingga terdapat 30 satuan percobaan. Apabila hasil uji $\mathrm{F}(\alpha=5 \%)$ menunjukkan pengaruh nyata, maka dilakukan uji lanjutan menggunakan Uji Duncan Multiple Range Test (DMRT) pada taraf 5\%.

Persiapan lahan diawali dengan pengolahan lahan pada petak-petak percobaan yang berukuran $4 \mathrm{~m} \times 5 \mathrm{~m}$, jarak antar petak perlakuan $50 \mathrm{~cm}$ dan jarak antar kelompok (ulangan) $100 \mathrm{~cm}$. Pemberian kapur dolomit sebanyak 2 ton ha ${ }^{-1}$ dilakukan 1 minggu sebelum tanam. Aplikasi perlakuan pupuk kandang ayam dilakukan 2 minggu sebelum tanam. Benih ditanam dengan jarak tanam $75 \mathrm{~cm} \times 40 \mathrm{~cm}$ sebanyak 2 biji per lubang tanam dan diberi karbofuran 5 butir per lubang tanam. Petakan dengan perlakuan CMA diberi CMA sebanyak 10 g per lubang tanam. Pemberian pupuk anorganik $50 \%$ dari dosis rekomendasi untuk dosis pupuk kandang $5,10,15$, dan 20 ton $\mathrm{ha}^{-1}$ sedangkan untuk dosis 0 ton ha $^{-1}$ diberi pupuk anorganik sebanyak $100 \%$ dosis rekomendasi (135 kg N ha ${ }^{-1}$ dalam bentuk pupuk urea, $36 \mathrm{~kg}$ P2O5 ha ${ }^{-1}$ dalam bentuk pupuk SP-18, dan $30 \mathrm{~kg} \mathrm{~K} 2 \mathrm{O} \mathrm{ha}^{-1}$ dalam bentuk pupuk $\mathrm{KCl}$ ). Pemeliharaan meliputi kegiatan penyulaman, pengendalian OPT, pembumbunan, dan penyiraman. Analisis infeksi CMA yang dilakukan pada akar tanaman jagung pada fase vegetatif maksimum. Pemanenan dilakukan saat terbentuk black layer atau pada saat kelobot dan rambut jagung mengering serta biji apabila ditekan kuku tidak berbekas. Pengeringan dan pemipilan dilakukan pengeringan dengan panas matahari selama 3 hari yang selanjutnya dipipil.

Parameter yang diamati antara lain: persentase daya tumbuh $(\%)$, tinggi tanaman $(\mathrm{cm})$, jumlah daun, diameter batang $(\mathrm{cm})$, umur tasseling (hari setelah tanam (HST)), umur silking (HST), umur panen (HST), derajat infeksi akar CMA (\%), komponen hasil (panjang tongkol (cm), lingkar tongkol (pangkal, tengah, dan ujung (cm)) dan hasil produksi jagung berupa: bobot brangkasan, bobot tongkol, dan bobot pipilan. Pengamatan hasil jagung dilakukan pula pada petak ubinan berukuran $2.5 \mathrm{~m}$ x $2.5 \mathrm{~m}$.

\section{HASIL DAN PEMBAHASAN}

Fase reproduktif tanaman jagung diawali dengan munculnya bunga jantan (tassel) pada umur 65 HST dan bunga betina (silk) pada umur 69 HST. Panen dilakukan sebulan setelah tanaman berbunga yaitu pada umur 98 HST yang ditandai dengan terbentuknya black layer, kelobot, dan rambut jagung yang mengering. Berdasarkan analisis secara statistik (ANOVA taraf 5\%) dosis pupuk kandang ayam memberikan pengaruh nyata terhadap pertumbuhan dan produksi jagung sedangkan secara umum perlakuan CMA serta interaksi antara pupuk kandang ayam dan CMA tidak menunjukkan pengaruh nyata.

\section{Derajat Infeksi Akar}

Perlakuan dengan CMA memberikan derajat infeksi yang lebih besar $(51.31 \%)$ dan berbeda nyata dengan perlakuan tanpa CMA (16.89\%). Dosis pupuk kandang ayam tidak memberikan pengaruh nyata terhadap derajat infeksi akar tanaman jagung.

Terdapatnya infeksi akar pada perlakuan tanpa CMA mengindikasikan bahwa terdapat CMA indigenous di lahan pertanaman jagung. Perlakuan dengan CMA menunjukkan infeksi akar yang cukup tinggi. Hal ini membuktikan bahwa CMA yang digunakan dapat tumbuh baik pada kondisi percobaan. Zuhry dan Puspita (2008) menyatakan bahwa peningkatan pemberian CMA yang diikuti dengan meningkatnya infeksi akar akan memproduksi jalinan hifa secara intensif sehingga akan meningkatkan kapasitas penyerapan unsur hara. Selanjutnya dijelaskan pula bahwa semakin banyak akar yang terinfeksi maka semakin besar pula tingkat penyerapan hara terutama pada tanah yang miskin unsur hara. 


\section{Pertumbuhan Vegetatif}

Parameter pertumbuhan vegetatif yang diamati pada 9 MST meliputi tinggi tanaman, jumlah daun, dan diameter batang. Pemberian CMA memberikan pengaruh nyata pada tinggi tanaman jagung umur 9 MST, perlakuan CMA menunjukkan tinggi tanaman yang lebih tinggi $(228.08 \mathrm{~cm})$ dibandingkan tanpa CMA (216.01 $\mathrm{cm})$ sedangkan pada parameter jumlah daun maupun diameter batang perlakuan CMA ini tidak memberikan pengaruh nyata. Pengaruh dosis pupuk kandang ayam terhadap parameter pertumbuhan vegetatif tanaman jagung dapat dilihat pada Tabel 1 .

Tabel 1. Parameter pertumbuhan vegetatif tanaman jagung umur 9 mst pada perlakuan dosis pupuk kandang ayam

\begin{tabular}{cccc}
\hline $\begin{array}{c}\text { Dosis pupuk } \\
\text { kandang ayam } \\
\left(\text { ton ha }^{-1}\right)\end{array}$ & $\begin{array}{c}\text { Tinggi } \\
\text { tanaman } \\
(\mathrm{cm})\end{array}$ & $\begin{array}{c}\text { Jumlah } \\
\text { daun } \\
(\text { helai })\end{array}$ & $\begin{array}{c}\text { Diameter } \\
\text { batang } \\
(\mathrm{cm})\end{array}$ \\
\hline 0 & $205.83 \mathrm{~d}$ & $13.02 \mathrm{~b}$ & $2.04 \mathrm{~b}$ \\
5 & $214.60 \mathrm{c}$ & $13.25 \mathrm{~b}$ & $2.05 \mathrm{~b}$ \\
10 & $221.98 \mathrm{bc}$ & $13.43 \mathrm{ab}$ & $2.20 \mathrm{a}$ \\
15 & $228.33 \mathrm{~b}$ & $13.77 \mathrm{a}$ & $2.27 \mathrm{a}$ \\
20 & $239.49 \mathrm{a}$ & $13.83 \mathrm{a}$ & $2.28 \mathrm{a}$ \\
\hline
\end{tabular}

Keterangan: Nilai pada kolom yang sama yang diikuti oleh huruf yang sama menunjukkan tidak berbeda nyata berdasarkan uji DMRT pada taraf 5\%

Dosis pupuk kandang ayam sebanyak 20 ton $\mathrm{ha}^{-1}$ memberikan tinggi tanaman paling tinggi $(239.49 \mathrm{~cm})$ dan berbeda nyata dengan semua perlakuan. Tinggi tanaman terendah diperoleh pada penggunaan pupuk kandang ayam sebanyak 0 ton $\mathrm{ha}^{-1}(205.83 \mathrm{~cm})$.

Berdasarkan hasil analisis regresi, tinggi tanaman jagung pada 9 MST memberikan respon linear hingga dosis pupuk kandang ayam 20 ton ha $^{-1}$ dengan persamaan $y=205.8+1.6 x(R 2=$ 0.87). Hal ini menunjukkan setiap penambahan dosis pupuk kandang ayam akan menyebabkan peningkatan terhadap tinggi tanaman jagung. Hubungan antara dosis pupuk kandang ayam dengan tinggi tanaman jagung ditunjukkan pada Gambar 1.

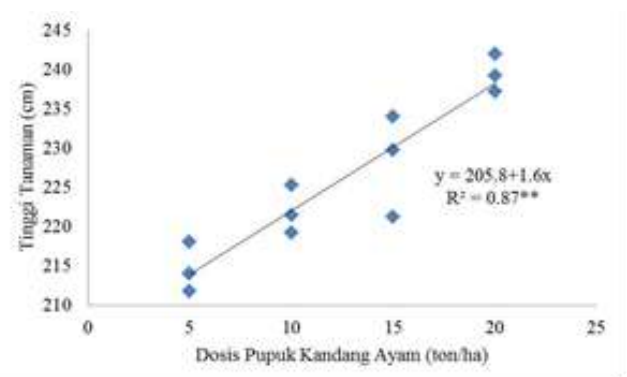

Gambar 1. Hubungan dosis pupuk kandang ayam dengan tinggi tanaman jagung
Dosis pupuk kandang ayam sebanyak 20 ton $\mathrm{ha}^{-1}$ menghasilkan jumlah daun paling banyak (13.83 helai) dan tidak berbeda nyata dengan dosis 15 ton $\mathrm{ha}^{-1}$. Dosis pupuk kandang ayam sebanyak 0 ton $\mathrm{ha}^{-1}$ memberikan jumlah daun paling sedikit namun tidak berbeda nyata dengan dosis 5 ton $\mathrm{ha}^{-1}$. Dosis 10 ton $\mathrm{ha}^{-1}$ memberikan jumlah daun yang tidak berbeda nyata dengan semua perlakuan.

Dosis pupuk kandang ayam sebanyak 20 ton $\mathrm{ha}^{-1}$ menghasilkan ukuran diameter batang paling besar $(2.28 \mathrm{~cm})$, namun tidak berbeda nyata dengan dosis 10 dan 15 ton $\mathrm{ha}^{-1}$. Dosis 0 ton $\mathrm{ha}^{-1}$ menghasilkan diameter batang yang paling kecil tetapi tidak berbeda nyata dengan dosis 5 ton ha ${ }^{-1}$. Hal ini menunjukkan bahwa pemberian pupuk kandang berpengaruh terhadap tinggi, jumlah daun, dan diameter tanaman jagung. Semakin tinggi dosis pupuk kandang ayam yang diberikan maka pertumbuhan vegetatif tanaman jagung semakin baik. Hal tersebut dapat disebabkan kandungan unsur hara N, P, dan Kalium (K) yang cukup tinggi pada pupuk kandang ayam memungkinkan semakin banyak pupuk kandang yang diberikan maka jumlah unsur-unsur tersebut semakin banyak pula. Susanti et al. (2008) menyatakan bahwa tersedianya $\mathrm{N}, \mathrm{P}$, dan $\mathrm{K}$ pada pupuk kandang ayam meningkat sejalan dengan peningkatan dosis pupuk kandang ayam tersebut. Selain itu, Yusnaini (2009) menyatakan bahwa pupuk kotoran ayam mengandung bahan organik yang memiliki $\mathrm{pH}$ dan kandungan kalsium yang tinggi. Unsur hara yang terkandung dalam pupuk kandang ayam terutama unsur hara makro yang berupa $\mathrm{N}$, $\mathrm{P}$, dan $\mathrm{K}$ berguna bagi pertumbuhan tanaman. Yuwono (2007) menyatakan bahwa unsur $\mathrm{N}$ dibutuhkan untuk pertumbuhan vegetatif tanaman, unsur $\mathrm{K}$ dapat memperkuat tubuh tanaman sehingga batang lebih kokoh dan kuat, dan unsur $\mathrm{P}$ digunakan untuk merangsang pembungaan dan pembuahan, pertumbuhan akar, dan pembentukan biji.

\section{Komponen Hasil}

Dosis pupuk kandang ayam tidak berpengaruh nyata terhadap panjang tongkol, tetapi berpengaruh nyata terhadap lingkar tongkol. Tabel 2 merupakan ukuran tongkol jagung pada perlakuan dosis pupuk kandang ayam. Dosis pupuk kandang ayam sebanyak 5 ton $\mathrm{ha}^{-1}$ menghasilkan lingkar tongkol yang paling kecil dan berbeda nyata dengan semua perlakuan. Dosis pupuk kandang ayam sebanyak 0 ton $\mathrm{ha}^{-1}$ menunjukkan lingkar tongkol yang paling besar namun tidak berbeda nyata dengan dosis 10,15 , dan 20 ton $\mathrm{ha}^{-1}$. Dosis pupuk kandang ayam 
sebanyak 5 ton ha $^{-1}$ menghasilkan lingkar tongkol paling kecil, hal ini diduga karena kandungan unsur hara pada dosis tersebut belum mencukupi kebutuhan tanaman terutama dalam penyediaan unsur $\mathrm{P}$

Tabel 2. Rata-rata ukuran tongkol jagung pada perlakuan dosis pupuk kandang ayam

\begin{tabular}{ccc}
\hline $\begin{array}{c}\text { Dosis pupuk } \\
\text { kandang ayam } \\
\left(\text { ton } \mathrm{ha}^{-1}\right)\end{array}$ & $\begin{array}{c}\text { Panjang tongkol } \\
(\mathrm{cm})\end{array}$ & $\begin{array}{c}\text { Lingkar tongkol } \\
(\mathrm{cm})\end{array}$ \\
\hline 0 & $15.86 \mathrm{a}$ & $15.04 \mathrm{a}$ \\
5 & $14.78 \mathrm{a}$ & $14.24 \mathrm{~b}$ \\
10 & $14.17 \mathrm{a}$ & $14.83 \mathrm{a}$ \\
15 & $14.62 \mathrm{a}$ & $14.99 \mathrm{a}$ \\
20 & $16.25 \mathrm{a}$ & $14.84 \mathrm{a}$ \\
\hline
\end{tabular}

Keterangan: Nilai pada kolom yang sama yang diikuti oleh huruf yang sama menunjukkan tidak berbeda nyata berdasarkan uji DMRT pada taraf 5\%

. Amin (2008) menyatakan bahwa untuk mendapatkan hasil yang baik dibutuhkan unsur $\mathrm{P}$ yang cukup, karena kekurangan unsur $\mathrm{P}$ terutama pada saat berbunga (perkembangan generatif) dapat menyebabkan pembentukan tongkol dan biji terganggu. Apabila tanaman menyerap hara dalam jumlah yang cukup untuk kebutuhannya maka hasil fotosintat yang dihasilkan dan ditranslokasikan ke bagian tongkol semakin besar. Semakin panjang ukuran tongkol dan semakin besar lingkar tongkol maka bobot tongkol dan pipilan yang dihasilkan pun semakin besar.

\section{Bobot Brangkasan dan Produksi}

Dosis pupuk kandang ayam berpengaruh nyata terhadap bobot brangkasan per tanaman dan berpengaruh sangat nyata terhadap bobot brangkasan per petak dan bobot tongkol per petak, namun tidak berpengaruh nyata terhadap bobot tongkol per tanaman.

Dosis pupuk kandang ayam sebanyak 20 ton ha ${ }^{-1}$ memberikan rata-rata bobot brangkasan per tanaman yang paling tinggi sedangkan dosis 0 ton ha $^{-1}$ memberikan rata-rata bobot brangkasan yang paling rendah. Bobot brangkasan per tanaman pada dosis pupuk kandang ayam sebanyak 5 dan 10 ton ha $^{-1}$ tidak berbeda nyata dengan semua perlakuan. Pada bobot brangkasan per petak, dosis pupuk kandang ayam 20 ton ha-1 menghasilkan rata-rata bobot brangkasan yang paling tinggi dan dosis 0 ton ha ${ }^{-1}$ menghasilakan rata-rata bobot brangkasan paling rendah, selanjutnya dosis 5,10 , dan 15 ton $\mathrm{ha}^{-1}$ menunjukkan bobot brangkasan per petak yang tidak berbeda nyata. Bobot brangkasan berbanding lurus dengan tinggi tanaman, jumlah daun, dan diameter batang. Semakin baik pertumbuhan vegetatif tanaman jagung maka semakin besar bobot brangkasan yang dihasilkan. Pupuk kandang ini diketahui memiliki kandungan nitrogen yang cukup tinggi. Unsur nitrogen ini dibutuhkan tanaman untuk pertumbuhan vegetatif (Tabel 3).

Tabel 3. Rata-rata bobot brangkasan dan bobot tongkol jagung pada perlakuan dosis pupuk kandang ayam

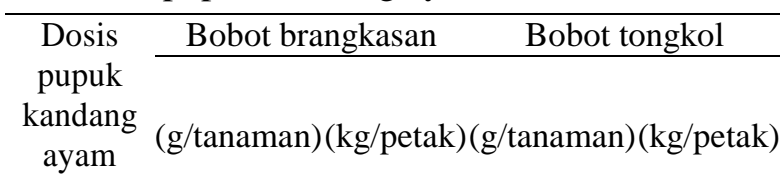
$\left(\right.$ ton ha $\left.^{-1}\right)$

$\begin{array}{lrlrl}0 & 215.42 \mathrm{~b} & 5.77 \mathrm{c} & 142.00 \mathrm{a} & 5.38 \mathrm{c} \\ & & 6.48 & & 5.66 \\ 5 & 253.19 \mathrm{ab} & \mathrm{bc} & 142.04 \mathrm{a} & \mathrm{bc} \\ & & 7.29 & & 6.00 \\ 10 & 267.25 \mathrm{ab} & \mathrm{bc} & 154.19 \mathrm{a} & \mathrm{ab} \\ 15 & 303.92 \mathrm{a} & 8.05 \mathrm{~b} & 156.75 \mathrm{a} & 6.29 \mathrm{a} \\ 20 & 321.75 \mathrm{a} & 9.84 \mathrm{a} & 166.47 \mathrm{a} & 6.49 \mathrm{a}\end{array}$

Keterangan: Nilai pada kolom yang sama yang diikuti oleh huruf yang sama menunjukkan tidak berbeda nyata berdasarkan uji DMRT pada taraf 5\%

Dosis pupuk kandang ayam memberikan rata-rata bobot tongkol per petak paling tinggi pada dosis 20 ton ha ${ }^{-1}$ namun tidak berbeda nyata dengan dosis 10 dan 15 ton ha ${ }^{-1}$. Dosis 0 ton ha ${ }^{-1}$ memberikan rata-rata bobot tongkol per petak paling rendah tetapi tidak berbeda nyata dengan dosis 5 ton $\mathrm{ha}^{-1}$. Semakin tinggi dosis pupuk kandang ayam yang diberikan maka semakin besar bobot tongkol yang dihasilkan. Hal ini diduga berhubungan erat dengan besarnya fotosintat yang ditranslokasikan ke bagian tongkol. Semakin besar fotosintat yang ditranslokasikan ke tongkol maka semakin meningkat pula berat tongkol.

Tabel 4. Rata-rata bobot pipilan jagung pada perlakuan dosis pupuk kandang ayam

\begin{tabular}{ccc}
\hline $\begin{array}{c}\text { Dosis pupuk kandang ayam } \\
\text { (ton ha-1) }\end{array}$ & \multicolumn{2}{c}{ Bobot pipilan } \\
\cline { 2 - 3 }$(\mathrm{g} /$ tanaman $)$ & $(\mathrm{kg} /$ petak) \\
\hline 5 & $92.82 \mathrm{a}$ & $4.00 \mathrm{bc}$ \\
10 & $91.78 \mathrm{a}$ & $3.89 \mathrm{c}$ \\
15 & $99.02 \mathrm{a}$ & $4.23 \mathrm{~b}$ \\
20 & $106.63 \mathrm{a}$ & $4.47 \mathrm{a}$ \\
\hline
\end{tabular}

Keterangan: Nilai pada kolom yang sama yang diikuti oleh huruf yang sama menunjukkan tidak berbeda nyata berdasarkan uji DMRT pada taraf 5\%

Tabel 4 menunjukkan bahwa dosis pupuk kandang ayam tidak berpengaruh nyata terhadap bobot pipilan per tanaman sedangkan pada bobot pipilan per petak menunjukkan pengaruh sangat nyata. Dosis pupuk kandang sebanyak 20 ton ha ${ }^{-1}$ memberikan rata-rata bobot pipilan per petak yang 
paling tinggi yaitu sebesar $4.60 \mathrm{~kg}$, namun tidak berbeda nyata dengan dosis 15 ton $\mathrm{ha}^{-1}(4.47 \mathrm{~kg})$. Dosis 5 ton $\mathrm{ha}^{-1}$ memberikan rata-rata bobot pipilan per petak paling rendah yaiu sebesar 3.89 $\mathrm{kg}$ namun tidak berbeda nyata dengan dosis 0 ton $\mathrm{ha}^{-1}(4.00 \mathrm{~kg})$.

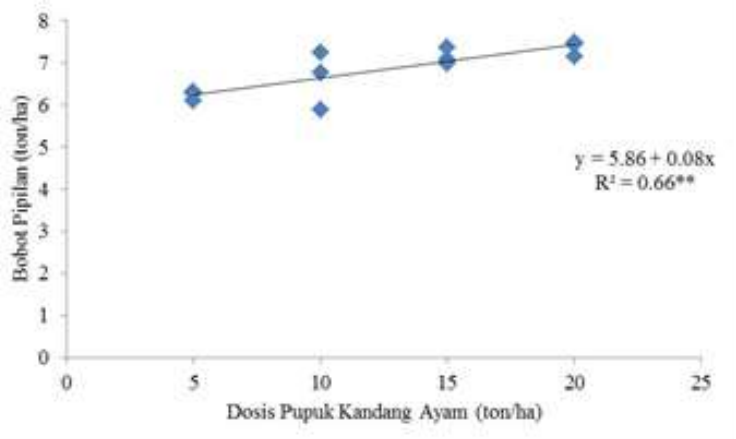

Gambar 2. Hubungan dosis pupuk kandang ayam dengan hasil pipilan kering jagung per ha

Berdasarkan hasil analisis regresi, bobot pipilan jagung per ha memberikan respon linear hingga dosis pupuk kandang ayam 20 ton $\mathrm{ha}^{-1}$ dengan persamaan $\mathrm{y}=5.86+0.08 \mathrm{x}\left(\mathrm{R}^{2}=0.66\right)$. Hal ini menunjukkan bahwa setiap penambahan dosis pupuk kandang ayam maka hasil pipilan kering jagung pun meningkat. Hubungan dosis pupuk kandang ayam terhadap hasil pipilan kering jagung per ha dapat dilihat pada Gambar 2.

Tabel 5 menunjukkan bahwa secara umum perlakuan CMA cenderung memberikan rata-rata bobot pipilan jagung per ha yang lebih tinggi dibandingkan tanpa penggunaan CMA. Selanjutnya terlihat bahwa semakin tinggi penggunaan dosis pupuk kandang ayam maka bobot pipilan jagung semakin besar, tetapi pada dosis 5 ton ha $^{-1}$ terlihat bahwa rata-rata bobot pipilan jagung yang dihasilkan lebih rendah dibandingkan perlakuan lainnya.

Tabel 6. Rata-rata bobot pipilan jagung per ha pada perlakuan cma dan dosis pupuk kandang ayam

\begin{tabular}{cccc}
\hline $\begin{array}{c}\text { Dosis pupuk } \\
\text { kandang ayam } \\
\left.\text { (ton ha }^{-1}\right)\end{array}$ & $\begin{array}{c}\text { Tanpa CMA Dengan CMA } \\
\text { (ton ha }\end{array}$ & Rata-rata \\
& & & \\
\hline 0 & 6.26 & 6.55 & 6.41 \\
5 & 6.08 & 6.39 & 6.24 \\
10 & 6.63 & 6.89 & 6.76 \\
15 & 7.15 & 7.17 & 7.16 \\
20 & 7.36 & 7.36 & 7.36 \\
\hline Rata-rata & 6.69 & 6.87 & \\
\hline
\end{tabular}

Dosis pupuk kandang ayam sebanyak 20 ton ha ${ }^{-1}$ memberikan rata-rata bobot pipilan jagung per ha yang paling tinggi yaitu sebesar
7.36 ton $\mathrm{ha}^{-1}$ dan dosis 5 ton $\mathrm{ha}^{-1}$ memberikan bobot pipilan jagung kering per ha paling rendah $\left(6.24\right.$ ton $\left.\mathrm{ha}^{-1}\right)$. Penggunaan pupuk kandang ayam dapat meningkatkan rata-rata hasil pipilan jagung kering per ha sebanyak $5.54 \%$ pada dosis 10 ton $\mathrm{ha}^{-1}, 11.79 \%$ pada dosis 15 ton ha ${ }^{-1}$, dan $14.91 \%$ pada dosis 20 ton ha ${ }^{-1}$ sedangkan pada dosis 5 ton $\mathrm{ha}^{-1}$ justru menurunkan rata-rata bobot pipilan jagung per ha sebanyak $2.65 \%$ dibandingkan penggunaan dosis 0 ton ha $^{-1}$. Rata-rata produksi pipilan jagung pada kondisi penelitian lebih tinggi dibandingkan rata-rata produksi jagung nasional (4.41 ton $\left.\mathrm{ha}^{-1}\right)$, akan tetapi masih dibawah potensi hasil jagung varietas Bisma ( 7.5 ton $\mathrm{ha}^{-1}$ ).

Penggunaan dosis pupuk kandang ayam sebanyak 5 ton $\mathrm{ha}^{-1}$ dengan $50 \%$ dosis pupuk anorganik belum mampu mengimbangi hasil pada penggunaan dosis 0 ton ha ${ }^{-1}$, karena penggunaan pupuk anorganik sebanyak $100 \%$ dosis rekomendasi pada dosis 0 ton ha $^{-1}$. Yusnaini (2009) menyatakan bahwa sebagai akibat dari perbaikan kualitas tanah melalui penambahan bahan organik, terutama kotoran ayam, produksi tanaman jagung mengalami peningkatan dan tidak berbeda jika dibandingkan dengan penggunaan pupuk anorganik $100 \%$.

Pemberian pupuk anorganik seperti urea, SP-36, dan $\mathrm{KCl}$ perlu dilengkapi dengan pemberian pupuk organik dan pupuk hayati (Juliardi, 2009). Kedua jenis pupuk tersebut dapat saling melengkapi kekurangan masing-masing. Juliardi (2009) menyatakan bahwa kelemahan pupuk anorganik antara lain dapat menyebabkan kerusakan struktur tanah seperti tanah menjadi lebih keras dan $\mathrm{pH}$ tanah menjadi lebih masam namun kelebihannya mempunyai kandungan hara yang tinggi dan segera tersedia bagi tanaman. Sementara itu kekurangan pupuk organik seperti kandungan hara yang rendah dan tidak segera tersedia bagi tanaman, namun kelebihannya yaitu dapat memperbaiki kualitas tanah.

Penggunaan CMA hanya meningkatkan bobot pipilan jagung per ha sebanyak $2.63 \%$ dibandingkan tanpa penggunaan CMA. Apabila dilihat dari hasil infeksi akar menunjukkan bahwa tingkat infeksi akar pada perlakuan dengan CMA jauh lebih besar dibandingkan perlakuan tanpa CMA. Terdapatnya infeksi inokulum cendawan pada akar tanaman dan terdapatnya ketidaksesuaian dengan respon pertumbuhan ataupun produksi tanaman jagung diduga disebabkan adanya persaingan dalam mendapatkan hasil fotosintat terutama karbohidrat antara tanaman inang dan CMA. Karbohidrat dibutuhkan tanaman untuk meningkatkan pertumbuhan jaringan tanaman menjadi terbatas ketersediaannya akibat pengambilan karbohidrat 
yang dilakukan oleh mikoriza tersebut. Menurut Delvian (2005) adakalanya inokulasi CMA dapat mengakibatkan terhambatnya pertumbuhan tanaman yang dikolonisasi. Selanjutnya dijelaskan pula bahwa jika jumlah biomass CMA lebih dari $17 \%$ dari berat kering akar, menyebabkan akar bermikoriza memerlukan energi lebih banyak dibandingkan dengan akar yang tidak bermikoriza.

\section{KESIMPULAN}

Dosis pupuk kandang ayam berpengaruh terhadap pertumbuhan dan produksi tanaman jagung. Penggunaan pupuk kandang ayam hingga dosis 20 ton ha $^{-1}$ memberikan pengaruh linear terhadap pertumbuhan dan produksi jagung. Hal ini berarti semakin tinggi penggunaan dosis pupuk kandang ayam maka pertumbuhan dan produksi tanaman jagung semakin meningkat. Pemberian CMA secara statistik tidak menunjukkan pengaruh nyata, namun hasil rata-rata menunjukkan tanaman jagung yang diberi CMA menghasilkan pertumbuhan dan produksi jagung yang lebih tinggi dibandingkan tanpa CMA. Secara umum, tidak terdapat interaksi antara dosis pupuk kandang ayam dan CMA terhadap pertumbuhan dan produksi jagung.

\section{DAFTAR PUSTAKA}

Amin, N.S. 2008. Pengaruh kascing dan pupuk anorganik terhadap efisiensi serapan $\mathrm{P}$ dan hasil jagung manis (Zea mays saccharata Sturt) pada tanah alfisols jumantono [skripsi]. Surakarta (ID): Universitas Sebelas Maret.

[BPS] Badan Pusat Statistik. 2011. Produksi Jagung [Internet]. [diunduh $2011 \mathrm{Mei} 21]$. Tersedia pada: http//www.bps.go.id/.

Delvian. 2005. Respon pertumbuhan dan perkembangan cendawan mikoriza arbuskula dan tanaman terhadap salinitas tanah. Medan (ID): USU Repository.

Juliardi, I. 2009. Pemberian Pupuk Berimbang untuk Mengoptimalkan Hasil Gabah pada Pertanaman Padi [Internet]. [diunduh 2011 Jul 04]. Tersedia pada: http://perpadi.or.id/.
Mayerni, R., Hervani, D. 2008. Pengaruh jamur mikoriza arbuskula terhadap pertumbuhan tanaman selasih (Ocimum sanctum L.). Jurnal Akta Agrosia 11(1):7-12.

Mawardi, Djazuli, M. 2006. Pemanfaatan pupuk hayati mikoriza untuk meningkatkan toleransi kekeringan pada tanaman nilam. Jurnal Littri 12(1):38-43.

Mugnisjah, W.Q. 2008. Kinerja Pertanian Terpadu yang Menerapkan Konsep LEISA [Internet]. [diunduh 2010 Nov 05]. Tersedia pada: http://kecubung6.com/.

Rosliani, R., Y. Hilman, Sumarni, N. 2006. Pemupukan fosfat alam, pupuk kandang domba, dan inokulasi cendawan mikoriza arbuskula terhadap pertumbuhan dan hasil tanaman mentimun pada tanah masam. Jurnal Hortikultura 16(1):21-30.

Susanti, H., Aziz, S.A., Melati, M. 2008. Produksi biomassa dan bahan bioaktif kolesom (Talinum triangulare (Jacq.) Willd) dari berbagai asal bibit dan dosis pupuk kandang ayam. Bul. Agron. 36(1):48-55.

Wachjar, A., Y. Setiadi, Yunike, , N. 2002. Pengaruh inokulasi dua spesies cendawan mikoriza arbuskula dan pemupukan fosfor terhadap pertumbuhan dan serapan fosfor tajuk bibit kelapa sawit (Elaeis guineensis Jacq.). Buletin Agronomi 30(3):69-74.

Yusnaini, S. 2009. Keberadaan mikoriza vesikular arbuskular pada pertanaman jagung yang diberi pupuk organik dan anorganik jangka panjang. J. Tanah Trop. 14(3): 253-26.

Yuwono, N.W. 2007. Unsur Hara Dalam Tanah (Makro dan Mikro) [Internet]. [diunduh 2011 Jul 06]. Tersedia pada: www.nasih.staff.ugm.ac.id/.

Zuhry, E., Puspita, F. 2008. Pemberian cendawan mikoriza arbuskular (CMA) pada tanah podzolik merah kuning (PMK) terhadap pertumbuhan dan produksi kedelai (Glycine $\max ($ L.) Merill). Sagu 7(2):25-29. 